\title{
Security Issues of Archaeological Sites and the Effect of Technological Developments in the Context of Examples
}

\author{
Örnekler Bağlamında Arkeolojik Alanların Güvenlik Problemleri ve Teknolojik Gelişmelerin Etkisi
}

Can Ozan Tuncer, Dr. Öğr. Üyesi, Van Yüzüncü Yil Üniversitesi, E-posta: canozantuncer@gmail.com

https://doi.org/10.47998/ikad.984067

Keywords:

Cultur,

Security,

Technology,

Security Risk,

Communication.
Anahtar Kelimeler:

Kültür,

Güvenlik,

Teknoloji,

Güvenlik Riski,

İletişim.

\section{Abstract}

Turkey is home to the most prominent ancient civilizations in history. It is crucial both for Turkey and world history that these lands, which have been the cradle of ancient civilizations, first-age civilizations, great empires, and states, should be preserved well. Apart from the traditional security needs of cultural areas, the study covers many different issues such as using new technologies in the security of these areas, increasing the attractiveness of the cultural regions as well as the safety of the environment, structure, and artefacts and visitors. The primary goal of this research was to identify the security and safety risks of three major archaeological sites. To that end, an observational study was conducted at the archaeological sites Mount Nemrut, the Ancient City of Perre and Göbeklitepe. Analysis of field notes suggested that risks that these three major archaeological sites face could be summarised as institutional and structural risks, natural risks and human activity-related risks. Research implications are discussed in the paper.

\section{$\ddot{O} z$}

Türkiye, tarihin en önemli antik uygarlıklarına ev sahipliği yapmaktadır. Kadim medeniyetlerin, ilk çağ medeniyetlerinin, büyük imparatorlukların ve devletlerin beşiği olan bu toprakların iyi korunması hem Türkiye hem de dünya tarihi için çok önemlidir. Çalışma, kültürel alanların geleneksel güvenlik ihtiyaçları dışında, bu alanların güvenliğinde yeni teknolojilerin kullanılması, kültürel bölgelerin çekiciliğinin artırılması, çevre, yapı, eser ve ziyaretçilerin güvenliği gibi birçok farklı konuyu kapsamaktadır. Bu araştırmanın birincil amacı, üç büyük arkeolojik alanın güvenlik ve güvenlik risklerini belirlemektir. Bu amaçla Nemrut Dağı, Perre Antik Kenti ve Göbeklitepe arkeolojik alanlarında gözlemsel bir çalışma yapılmıştır. Saha notlarının analizi, bu üç büyük arkeolojik alanın karşı karşıya olduğu risklerin, kurumsal ve yapısal riskler, doğal riskler ve insan faaliyetlerinin yol açtığ1 riskler olmak üzere üç temel başlıkta özetlenebileceğini göstermiştir. Araştırma sonuçları makalede tartışılmaktadır. 


\section{Introduction}

Turkey is home to the greatest and most prominent ancient civilizations in history. The knowledge gained about these civilizations, which have found a vast place in world history, sheds light on human history about many elements such as their social lives, trade relations, military order, and religious beliefs. According to the Ministry of Culture and Tourism ${ }^{1}$, there are two hundred and one museums and one hundred and forty-two archaeological sites in Turkey, which are open for visitors from all over the world. The wealth of the country's land provides valuable information about these civilizations' lives, social and commercial networks and, more importantly, gives an overview of the significant stages of human history. In this vein, Nickens (1991) argues that there are not many places like archaeological sites that can be regarded as a resource supplying modern people with knowledge of past civilizations. This means that an archaeological site is one of the few portals that can inform everyday people about previous lives.

Turkey, which has a wealthy cultural value in terms of geography, cultural tourism, and cultural assets hidden in its fertile soil, becomes a starting point for discovering these civilizations' identities, understanding the flow of history and interpreting the future. At this point, determining the strategies to unearth the wealth and diversity of Turkey's cultural heritage and their introduction, protection, reparation/restoration, and storage to hand them down to the next generations becomes a vital issue since "for most periods of human history, archaeological resources provide the primary, and often the sole, source of information" (Elia, 1997, p.85). Moreover, the "efforts to protect the cultural property, which is one of the concrete elements of the cultural heritage, are carried out not because of the economic values of these properties, but for their sentimental value in the cultural and world heritage" (Töngör, 2018, p.91). In other words, displaying these cultural assets in their first-place means carrying humanity's collective consciousness into the future. Hence, it is necessary to meticulously preserve and protect the cultural assets to analyze both the past and the future.

Within this framework, the harmony between legal regulations and national and international agreements is essential for the artefacts exhibited in the archaeological site since these remnants do not have the capacity to protect themselves from external conditions, and they can't resist time with its destructive power because of the constructional peculiarities they have (Rizzi, 2007). Therefore, it is necessary to be prepared for natural risk factors such as earthquakes, floods, typhoons, tornadoes, lightning strikes, and human-made risk factors like sudden fires and arson to ensure the safety of these areas. For this reason, it is of great importance to carry out research to determine and minimize the risk factors for each cultural area.

Apart from natural factors, human-made distortion can be counted as a significant issue for protecting the artefacts within the cultural sites since those places host a wide variety of visitors from different age groups and every walk of life. "Archaeological sites and historical places are major tourist attractions worldwide ... (and) an archaeological and historical tourism destination could be anything of interest ranging from museums

1 https://kvmgm.ktb.gov.tr/TR-43253/genel-mudurlugumuze-bagli-muzeler-ve-orenyerleri.html The numbers are retrieved from the official website of the related ministry on $28^{\text {th }}$ of February 2021 
where artefacts are housed to the actual excavation sites among themselves" (Chowdhury and Ahmed, 2015, p.2). Therefore, it can be understood that the number of people that want to see archaeological sites can be enormous.

From the moment visitors enter the borders of an archaeological site, they may present an ignorant attitude out of their curiosity and enthusiasm; thus, this can cause significant damages to the artefacts. Apart from visitors, there may also be practices caused by human neglect/disregard on ensuring cultural areas' safety. Additionally, site vandals maliciously deface or damage archaeological sites, monuments, and objects. Examples of vandalism include the "damaging of buildings and monuments from gunfire and the defacing of prehistoric rock paintings" (Nafziger \& Paterson \& Renteln, 2010, p.253). For this reason, while there are many common ways to ensure the safety of public spaces in general, archaeological sites become a case in themselves. In addition to the physical strength of buildings, warehouses, gardens, and storages, the need to protect museums and archaeological sites in general with technology-oriented solutions against the destruction caused by natural and human factors is a common problem of cultural areas.

Although the security of cultural areas evaluated in line with human rights, this has come into prominence in recent years. Many studies have been conducted on this problem in Turkey from the past to the present. Baraldi and her colleagues (2012), for example, researched this issue, and they believe that many of the archaeological sites located in Turkey are inadequately protected or conserved even though those areas are protected by both local and central governments by laws and regulations. They also note the lack of cooperation among related disciplines such as archaeologists, restorers, and museologists as another significant issue for the preservation of archaeological sites.

Preserving cultural assets and ensuring the continuity of the conservation process can differ depending on the nature of the artefacts and the places in which they are located (museums and archaeological sites). Today, multifaceted protection conditions against humidity, light, risk steaming natural disasters, landscaping, safety conditions of the environment where the cultural asset is located have gone beyond a point that individual efforts can overcome alone. Comprehensive studies are needed to be carried out to ensure the conservation and sustainability of cultural areas where cultural assets are located.

International terrorism may also pose a significant security threats to archaeological sites. Since the terrorism can be understood as the threat or premeditated use of brutal violence by subnational groups to obtain a political, ideological or religious objective through the intimidation of the population. Terrorist activities directed to cultural heritage of a given country may cause severe damages to heritage symbols and places of major tourist interest (Fernández Laso, 2020). Given that Turkey is targeted by terrorist groups such as ISS and PKK, the protection cultural heritages is of significance importance.

Modern and developed societies tend to take all measures to protect cultural values belonging to past civilizations and transfer them to future generations, considering this a priority within their national duties. In this context, it is necessary to understand the phenomenon of security to create an awareness of archaeological sites that might preserve 
cultural values. The security of archaeological sites where cultural values are located will be possible by focusing on technology and new developments.

\section{Present Study}

"The significance of cultural heritage is articulated by evoking the necessity for protection, through conservation and the restoration of historic sites, monuments and artefacts, the preservation of cultural landscapes, and the safeguarding of 'traditional' practices (such as rituals and music) and 'indigenous' knowledge" (Tanaka, 2013). As important as their discovery, making archaeological sites' promotion in the desired manner, preserving them in high-quality conditions, and taking advantage of technology's innovations like modern displaying modern are perhaps even more critical. These values should not be allowed to be destroyed with ignorance and vandalism, which alone is a relatively minor, though harmful, cause of damage to archaeological resources. In Turkey, which can be described as a heaven of cultural values, shortcomings exist in the security measures taken to protect these values from all-natural and human risks.

The aim of this study was to explore the security risks archaeological sites are exposed to. To that end, three criteria, namely the geographical location of the site, weather conditions and visitor density, were used to determine the areas to be observed. After the initial analyses, three archaeological sites, Mount Nemrut, the Ancient City of Perre, Göbeklitepe located in the South-eastern Anatolia region, were chosen as samples.

\section{Method}

Field research was carried out at three sites to explore security and safety risks. In this way, it was aimed to make suggestions that can be valid for the other archaeological sites in Turkey. Additionally, the results of the study conducted by the Department of Internal Security Strategies were incorporated into this research (İç Güvenlik Stratejileri Dairesi Başkanlığ 1 Yayınları, 2020). This research examined the security and safety breaches of major archaeological sites in Turkey.

The unstructured observation method was employed as a data collection tool to explore archaeological sites' security and safety risks. Observation can be either structured or unstructured. Structured observation, also known as systematic observation, requires pre-defined variables and tables to be filled during the field study (Baker, 2006).

On the other hand, observation can also be made in an unstructured manner. This type of application allows the researcher to conduct the observation in a more flexible way (Muhall, 2003). Unstructured observation is more effective when the study is not informed by prior research or theory. Hence, it is more exploratory in nature. The observations were made on the dates between December 2019 and January 2021 at three archaeological sites. Field notes were taken during the observations, and these notes were later transcribed and analyzed. 


\section{Background:}

\section{Conceptual Framework and Legislative Framework}

Although terms such as "cultural heritage" or "cultural value" have been used, over time, the term "cultural assets" have been considered to be more inclusive since it indicates cultural wealth. This shift in the terminology is mainly due to the efforts to narrow the scope of the assets since the term 'heritage', as Silverman and Ruggles (2007) suggest, refers to both "material culture - objects of art and daily use, architecture, landscape form - and intangible culture - performances of dance, music, theatre, and ritual, as well as language and human memory (p. 3). It is of no doubt that this definition includes more than physical objects that were handed down from past lives to the contemporary world. The term 'cultural value', on the other hand, is generally expressed by illustrating both cultur(al) and value. The term culture, as William (1976) proposes, "is one of the two or three most complicated words in the English language" (p.87). In the basic sense, it can be "defined as ... shared meanings assigned by ... members to things and persons around them" (Smith et al, 2002, p. 189). The simplest definition of the term 'value' in this context can be norms "among the building blocks of culture" (Hofstede, 1980, p.25). Even if this discussion over the terms and their related meaning can be extended, such an approach can reduce this research's limits. At the end of this development process, ensuring these cultural assets' security becomes an important issue due to architectural/ historical qualities and values they carry. Finally, the related law of the Turkish Republic defines the term cultural asset as follows:

Legislators of its assets, "the prehistoric and historical era of science, culture, religion and art-related or that prehistoric or historical periods of social life become the subject scientifically and culturally authentic valuable space on the ground or underwater, under all movable and immovable assets "were defined as (KTVKK m.3/a-1). Legislators to describe the cultural heritage, archaeological or archaeological qualities outweigh the qualifications is a priority. (Y1ldı, 2010, p.628) follows:

Bilgin and his colleagues (2020) summarize the legal framework in Turkey as

Museums Internal Service Regulation of Ministry of Culture and Tourism Inspection Board Law No 2863 in clause e of article 5. states that the protection of all immovable cultural properties is under the responsibility of museums.

Museology Guide prepared by the board mentioned above prepared within the scope of the protection of archaeological sites. It states that for the protection against any kind of threat of the im/movable cultural and natural assets should be provided by taking the necessary cautions. This guide also covers the security measures to be applied in museums and archaeological sites with how and in what ways. 


\section{The History and Significance of the Archaeological Sites}

\section{Mount Nemrut Archaeological Site}

"The story of Mount Nemrut is, in a sense, part of the history of the East and the West" (Şahin, 1998, p.36). It is one of the most glorious Hellenistic period remnants that was built by the King of Commagene, King Antiochos I, to show his gratitude to the gods and his ancestors.

It is located at the side of Mount Nemrut, which has a height of 2.1500. The monumental sculptures are spread over the east, west, and north terraces. The giant sculptures, which are well preserved, are made of limestone blocks and are 8-10 meters high. Mithradates established the region called Commagene in ancient times as an independent kingdom. The kingdom gained importance during his son Antiochos's I reign (62-32 AC). After losing the war against Rome in $72 \mathrm{AD}$, the kingdom's independence came to an end.

The summit of Mount Nemrut is not a place of settlement, but the Tumulus, "artificial hillocks on a flat plain, were burial grounds for the privileged in ancient times. The tumulus tradition was used from $2000 \mathrm{BC}$ to the 3rd-4th century AD, spanning Bulgaria, Greece, Central Asia and Southern Russia along with Anatolia and Syria" (Tan, 2016, p.33). On the summit, the sacred sites of Antiochos are also located. The Tumulus is situated in a crest above the Euphrates River gorges and plains. The Tumulus, 50 meters high and 150 meters in diameter, where the king's bones or ashes were placed in a chamber carved into the bedrock, was covered with small rock pieces and protected by them.

After the kingdom of Commagene was erased from history, the artefacts on Mount Nemrut were left in solitude for about two thousand years. While visiting the area as an officer in 1881, Karl Sester, a German engineer, came across the statues. After that, he informed the German consul in Izmir that the site was an Assyrian archaeological site. He believed so because he could not see the Greek inscriptions behind the pedestals where God's statues were placed.

Karl Sester made this mistake with the excitement of discovering giant sculptures. In 1882, Otto Puchstein and Karl Sester examined Mount Nemrut. Director of the Museum-i Humayun (Imperial museum) Osman Hamdi Bey came with a team in 1883 and conducted a researched on Nemrut. After World War II, American archaeologists Theresa Goell and German Karl Doerner conducted excavations and research in Nemrut and its region.

The Tumulus of Mount Nemrut, along with other artefacts and settlements in the region, was registered on 13.03.1986 with law no 2036 by the Supreme Council of Immovable Cultural and Natural Assets. After this law, following the application made by the Ministry of Culture and Tourism in 1987, the Tumulus of Mount Nemrut was accepted into the UNESCO World Cultural Heritage List. After adding the Tumulus of Mount Nemrut to the World Heritage List, The Council of Ministers declared the region where the Tumulus is located as a National Park with law no. 88/13.572. 
After the declaration of Mount Nemrut as a National Park, The Conservation Area boundary related to Nemrut was defined in a different law by the relevant Conservation Council. However, Nemrut Tumulus received its current status with Adiyaman Regional Council's law to protect cultural and natural assets dated 08.10.2001 and numbered 4365 . The issue was raised in the preparation phase of the Long-Circuit Development Plan of Mount Nemrut National Park and the immediate environment of Mount Nemrut. After that, this area has been declared a first-degree archaeological site. After a year, the area was also reported as a susceptible region following the National Parks Law numbered 2873.

\section{Ancient City Perre}

TheAncient City of Perre, one of the five major cities of the Kingdom of Commagene, known in ancient sources as Me'arath Gaza Pörön and Mesopotamia as Pirin and Perin, had geopolitical importance in the past due to being on the route connecting Melitene, known as Malatya today, to the capital Samosata which is now Samsat (Erarslan et al., 2010).

Known as Hierapolis (holy city), Perre joined the kingdom as a province of Persidas under the rule of Bishop loannes Perdos. Andreas of Samosata (Samsatli) mentioned some influential bishops in Perre in his letter to Alexander, indicating that the city was also an important city from a religious perspective. All this shows that the ancient city of Perre was a city of both spiritual and geopolitical importance in antiquity (Erarslan et al., 2010).

In ancient Roman sources, the beauty of its water is also mentioned, and it is described that it was used as a resting place by caravans, passengers, and armies. The Roman fountain from which the said water flows is still in use.

The Ancient City of Perre lost its importance after the Byzantine period and could never rise to its former glory again. On the original settlement part of the ancient city, there is a late-period settlement, today known as Ören district, yet still a village. The rock tombs found here are carved into the cliffs and have a great appearance.

Pirin caves located in the archaeological site of Adiyaman province (Pirin village) were declared a site by the Supreme Council of Real Estate Antiquities and Monuments with a law dated 12.02.1977 numbered A351. The archaeological site of Pirin (Perre) was declared an immovable cultural asset by Adana Council to protect cultural and natural assets with the law dated 01.06.1990 and numbered 583.

It is known that the original settlement area of the Ancient City of Perre is today under the Örenli District (Pirin Village). In this context, in 2007, the expropriation of the settlement remaining in the archaeological site of Pirin (Perre) was requested by individuals; at the request of the Ministry of Culture and Tourism, the expropriation issue was invited by the Public Housing Administration. It was stated by the Public Housing Administration that a $20,000,000 \mathrm{TL}$ allowance is needed for the expropriation of this area.

The Ministry of Culture and Tourism could not deposit the amount of this allowance into the Public Housing Administration account due to the lack of expropriation allowance 
in the fiscal year 2008. People of the region cannot build new structures, and they cannot make any renovations since the place they are living in is a first degree protected area. This has caused some of the houses in the area to be demolished.

\section{Göbeklitepe Archaeological Site}

Göbeklitepe archaeological site is located in 18 kilometres northeast of Şanliurfa city centre, near the village of Örencik. The area was discovered in 1963 during a surface survey conducted in partnership with the Universities of Istanbul and Chicago and identified as the V52 Neolithic settlement. The real value of the area began to be revealed with the excavations started after 1994. After these studies, it was understood that Göbeklitepe was a cult centre dating back 12 thousand years (Kurt and Göler, 2017).

In the middle of about 20 round and oval structures with a diameter of 30 meters, there are two 5-meter-high and " $T$ " shaped independent columns made of limestone. There are smaller columns on the inner walls of the buildings. The scientific data mentioned about Göbeklitepe provide essential information that requires a re-evaluation of the theoretical framework and re-dating related to the Neolithic period in archaeological studies. Göbeklitepe has been understood to be a unique sanctuary for the Neolithic period with its location, dimensions, dating and monumentality of its structures. Since the area remained untouched within its natural surroundings for 12 thousand years, it offers critical archaeological findings (Schmidt, 2010).

Göbeklitepe, a work of great organization and imagination, is the oldest monument of this size and, beyond the firsts, constitutes the zero point of history in many ways. When man lived as a hunter-gatherer, the construction of temples that required advanced architecture caused astonishment worldwide. Reflecting on the belief world of prehistoric life and the temples enriched with animist figures, Göbeklitepe has made one of the most critical discoveries of the archaeological world.

Göbeklitepe, the first temple built in the time of hunter-gatherer human communities, which are far from the concepts of settlement and agriculture, had not yet passed into city life, is promoted as the most significant archaeological discovery of recent years. The temple attracts all the attention as it was built approximately 7.500 years before the Egyptian Pyramids and Stonehenge in the United Kingdom, and how it was designed cannot be answered yet.

Göbeklitepe archaeological site is under the protection of Cultural and Natural Assets with a law numbered 2863. It is registered as a first-degree archaeological site by law No. 422 dated 27.09.2005 by the Directorate of the Regional Council for the protection of cultural assets of Diyarbakir. It is registered as a first-degree archaeological site. It was placed on the temporary list of World Heritage Sites by UNESCO in 2011 and moved to the permanent List in 2018. 


\section{Findings}

\section{Institutional and Structural Factors}

\section{Mount Nemrut}

The formation of the pedestrian path appeared to be a safety risk. These paths are made of stones. In the region, where frost events are intense during winter, the road becomes quite slippery in cold weather, causing visitors to be injured by sliding. There are no railings on the right and left sides of the pedestrian path, which poses a risk to children and the elderly who pass through there. Besides, visitors who want to take a picture of the landscape on the pedestrian path are putting themselves in danger by walking off the road.

Lack of safety equipment was another safety issue identified. It is observed that the security personnel are on duty in shifts on a 24-hour basis at the archaeological site of Mount Nemrut. Besides, the cultural area is kept under 24-hour surveillance with cameras stationed in various places in the area. These measures taken in the area reduce many risks, mostly illegal excavations. But it has been observed that the existing camera system cannot observe the entire region, and the main goal was protecting the statues located around the Tumulus. This poses a safety risk for visitors.

As mentioned before, weather conditions pose a great threat with the air temperature dropping down to -30 degrees centigrade in the archaeological site during winter. Because of the harsh weather conditions that dominate the area, the installed security cameras can get frozen. Therefore, the cameras are dismantled in winter so that they are not damaged due to freezing.

Another critical issue is the risk of cameras becoming unusable as a result of lightning strikes. Since the archaeological site is located in a high area, the cameras here attract lightning. Lightning rods were installed to prevent lightning from streaking on the cameras, but they were also insufficient. Such winter conditions cause risks that cannot be controlled since it will be hard to detect them.

The lack of a medical team on Mount Nemrut archaeological site was also a significant safety problem detected. Apart from the winter months, the archaeological site of Mount Nemrut receives intense local and foreign visitors. Incoming visitor profile consists of people of all ages and all walks of life. Visitors have to cross a steep road to reach the area where the statues are located, and they have great difficulty in doing so. It poses a significant problem to take any visitor with a prior health problem in case of an emergency to a medical centre since the nearest hospital (Kahta State Hospital) is $43 \mathrm{~km}$ away from the site.

\section{Ancient City of Perre}

Incomplete expropriation procedures were spotted as an essential safety issue. It is known that the main centre of the life of the ancient city is located under the residential area of the Örenli District. To uncover the Ancient City of Perre's living space, expropriation works started in the district in 2009. Especially with the expropriation efforts accelerated over the last 2-3 years, the evictions of the citizens living here continue today. But in 
the ancient city's archaeological site, where the main residential area is believed to be located, expropriation processes are relatively slow for various reasons. In the field study, it was found that the remains of the ancient city are used on the foundations and garden walls of houses in the Örenli District. It is believed that the delay of expropriation will cause more damage to such cultural assets.

The transportation and exhibition of the king's tomb (mosaic) was another issue identified. The mosaic, which has been found to belong to the Roman period and contains various motifs, is the largest mosaic found in the region until now. The top of the mosaic area was covered with landscaping, and a pedestrian path was made around it. In this way, it is aimed to protect the mosaic from natural factors and the destructive acts of malicious people. Rock tombs are located under the mosaic area, and it is believed that these graves belong to high-status people.

To reach the king's tomb, located outside the borders of the area where the rock tombs are located and surrounded by wire mesh, it is necessary to use the road passing through the Örenli District. This road narrows considerably in Örenli District. The road that comes immediately after the district is not suitable for vehicles to pass. It is very risky to use vehicles other than all-terrain ones to get to the cultural area, which is quite challenging to reach on foot due to its distance from rock tombs.

\section{Archaeological Site of Göbeklitepe}

Lack of technical equipment was a significant security risk identified. In the service area and ticket/museum card checkpoint, there is a turnstile system and a security cabin that reads visitors' tickets to the archaeological site. The security cabin has computers where images of cameras located in social areas and around the excavation site are monitored and recorded. Although the cameras present in the area have night vision features, at the end of the interviews, it was determined that there were blind spots in the area. Furthermore, the number of cameras was found to be insufficient. Security personnel working in the area stated that there are 15 cameras in the excavation area. Still, this number is not enough and, in a study conducted by a company, it was stated that only the excavation area should be monitored with at least 45 cameras.

Table 1:

Security Risks Related to Institutional and Structural Factors

\begin{tabular}{lll}
\hline Site & Structure of the pedestrian path \\
Lack of a Medical Team &
\end{tabular}




\section{Natural Risks}

\section{Mount Nemrut}

The severe weather condition was a significant natural risk at Mount Nemrut. One camera control centre and one prefabricated cabin for security guards are located at the bottom of the statues found in the eastern part of the site. This cabin is usually covered in snow in winter as it remains at the bottom part of the summit. For this reason, the security guards at the sites are located in the security cabin situated in the welcoming area outside of visiting hours in winter. From this point of view, the absence of personnel in the site other than visiting hours during cold periods creates a security weakness.

\section{Ancient City of Perre}

Fire risk is the primary safety issue at the Ancient City of Perre. The area where the Ancient City of Perre is located in an area with a steppe climate. Weeds grown in this area continually keep growing, although they are tried to be dried from time to time. In summer, the weeds that dry out in the Adiyaman Sun become very easily flammable. Since the rock tombs unearthed as a result of excavation are in the middle of these long weeds, they are the first to be damaged in a fire that may occur due to the ignition of these weeds will cause a fire to spread quickly.

\section{Archaeological Site of Göbeklitepe}

The presence of too many weeds in the excavation area increases the risk of fire in the site. However, wooden blocks previously used in railway construction were used to construct the visitor's walkway trail. In a possible fire, it was determined that these wooden blocks could ignite quickly due to the surrounding weeds' influence. Both the fact that there are too many weeds and the fact that wood blocks are difficult to extinguish when they start to burn are considered an element that will increase the damage that may occur due to a possible fire.

Another element detected as a result of the field survey is the possibility of damage to the artefacts unearthed caused by landslides in the excavation site area. It was stated that new excavations could not be carried out due to this risk. Another factor that triggers this risk is the rainwater that reaches up to the excavation area. Although the upper part of the excavation area was covered, it was stated by the authorities of the sites that when it rains, especially with the influence of the wind, rainwater fills the space where the artefacts are. Especially in the "Temple C" section, which is relatively open on the side, it was noted that a lot of rainwater came under the influence of the wind, which can also trigger a landslide. The research found that the artefacts found in this part of the excavation site gradually began to be destroyed due to drops of water falling inside. 
Table 2:

Security Risks Related to Natural Phenomenon

\begin{tabular}{lcrl} 
& Security Risks Related to Natural Phenomenon & Pöbeklitepe \\
\hline Site & Nemrut & & \\
Severe Weather Conditions & & &
\end{tabular}

\section{Human Activity Related Risks}

\section{Mount Nemrut}

Vandalism was identified as a major human-related problem. The tombs and monumental sculptures in Mount Nemrut were built by Commagene King Antioche I to show his gratitude to the gods and ancestors. But because of its name, the archaeological site is confused with the Nemrut, King of Babel, who threw Prophet Abraham to fire, and hence a negative view of the statues here may be formed among the public. Furthermore, since amateur people who guide visitors also present Nemrut as the same king who threw Abraham to fire, the public see the statues here as idols. Although there was no attack on the figures thanks to the measures taken, the authorities express a tendency in this direction.

\section{Ancient City of Perre}

Vandalism or vandalism is the act of consciously and willingly damaging a person or public property, vehicle, or product. The behaviour of intentionally and voluntarily harming a person or a public property, a vehicle, or a product is most frequently manifested in Turkey's cultural assets. Damage to cultural assets can be caused by ignorance, as well as by vandalism. Many negative behaviours, such as writing on cultural assets and destroying artefacts, are exhibited by people who don't have an awareness of this issue.

On the walls of the rock tombs located in the Ancient City of Perre, there is also graffiti written by visitors. Although visitors are kept under observation by officials within the site, similar events occur. Also, garbage thrown into the area distorts the visual of the cultural area. In general, the appearance of vandalism, which also exists in our country, also poses a risk to cultural assets.

In Turkey, illegal excavations are quite common, and "a significant proportion of the ongoing destruction is brought about by looters, acting from commercial motives, which are financed indirectly by private collectors of antiquities" (Brodie and Renfrew, 2005, p.344). There are many reasons behind these kinds of actions, such as the desire to make easy money and treating them as an adventure or hobby. Legends, rumours, or predictions spread among the public are highly sought after by people who have placed treasure hunting at the centre of their lives. Besides, malicious people who notice the interest in this issue also trick treasure hunters with qualified fraud techniques that they develop every day. 
Although some of the rock tombs have been enclosed in wire mesh with the landscaping, it is known to the region's people and authorities that the cultural area is spread over a wide area. It is believed that the area around the site, where there are no current excavations, is filled with rock tombs. Treasure hunters hoping to find the deceased's valuables in the graves have made illegal excavations attempts in this area from time to time. In the site, where there are no security guards in the current situation, it is quite difficult to prevent such activities. Reports are written by officers here only if they notice the incident and patrols by law enforcement officers at regular intervals do not carry a deterrent element. The vulnerability in this issue poses a risk to the cultural area.

\section{Archaeological Site of Göbeklitepe}

Another critical finding identified as a result of field research is that transportation to the neighbouring village Örencik is provided by a road through the main entrance. The mentioned village is reached by following an asphalt road built for access to the main entrance of the archaeological site. (The part where the relevant Connection Road is located is known as "Mardin Connection Road" in the region.) For this reason, citizens residing in the village use the main entrance door of the site to reach their villages. Generally, drivers who do not use the Şanlıurfa roadside prefer to pass through the site because it is closer. Security personnel at the site said that the route is used by citizens who want to go to the village. It was also found that there were quarrels between citizens and security guards in cases when they were not allowed. This situation creates a safety vulnerability for the site with no X-ray device at the vehicles' entry point.

Table 3:

Security Risks Related to Human Activities

\begin{tabular}{lllll}
\hline Site & Nemrut & Göbeklitepe \\
\hline Vandalism & & & \\
Illegal Excavation & & &
\end{tabular}

\section{Discussion and Conclusions}

Regulation on Identification and Registration of Immovable Cultural and Natural Properties to be Protected defines cultural assets as the immovable assets that need to be protected from prehistory and historical periods and related to science, religion, and fine arts (RT Official Gazette, 1987). It is crucial both for Turkey and world history that these lands, which have been the cradle of ancient civilizations, first-age civilizations, great empires, and states, should be preserved well. Apart from the traditional security needs of cultural areas, the study covers many different issues such as using new technologies in the security of these areas, increasing the attractiveness of the cultural regions as well as the safety of the environment, structure, and artefacts and visitors.

The primary goal of this research was to identify the security and safety risks of three major archaeological sites. To that end, an observational study was conducted at the 
archaeological sites Mount Nemrut, the Ancient City of Perre and Göbeklitepe. Analysis of field notes suggested that risks that these three major archaeological sites face could be summarised as institutional and structural risks, natural risks and human activity-related risks. Though these three major risk groups pose a significant threat to these sites, the stakes could be addressed easily.

Regarding Mount Nemrut, slippery pathways were another significant safety issue at Mount Nemrut, so rubber strips should be made on the road to prevent severe injuries. Further, construction of railings on the sides of the pedestrian path that surrounds the Tumulus from East to West should be built to avoid visitors from leaving the road or falling to the foot of the mountain located on the right side of the road.

Observation results indicate that the most prominent element of risk in the site is the absence of a medical team that will continuously work here. It will be useful to meet with the Ministry of Health officials and create a medical team that will work on a 24-hour basis in the cultural area. For this reason, an urgent prefabricated structure should be built in the site's welcoming area, and a sufficient number of medical teams' working in shifts should be placed there.

Regarding the Archaeological Site of the Ancient City of Perre, to preserve the cultural assets, it is vital to complete the expropriation process and operations to bring the ancient city's settlement to the surface and facilitate the places as a touristic one. The necessary allowance for expropriation should be provided, and the procedures should be completed immediately, or public land should be assigned to the local people, and they should be persuaded to go to those places by allocating public land.

As fire incidents in the site pose a risk to rock tombs, officials, and visitors every year, water tankers with a hose of at least 50 meters should be placed at specific locations in this vertical structure. Determination of the number and location of these water tankers should be made after a thorough exploration in the region by experts. Additionally, it should be ensured that the covered area's path, where the 135 square meter mosaic remains outside the area surrounded by rock tombs, should be temporarily re-organized and paved with stone until the expropriation operations are completed. Besides, for visitors who can reach the mosaic from the road passing through the site without ever entering the site, a temporary entrance and checkpoint should be built, and since the access to the rock tombs located under the mosaic is closed due to constant landslides, this section should be cleaned, the rock tombs should be maintained and opened to the public.

More importantly, an awareness of how essential cultural assets the Ancient City of Perre and rock tombs are should be created. It should be explained that increasing the cultural attractiveness of these cultural assets by protecting them from all kinds of damaging elements will significantly contribute to the region's tourism and economy. Especially in district schools, students should be provided with education; brochures should be distributed to the public. Citizens should be guided to embrace this cultural presence through activities to be held.

Regarding the Archaeological Site of Göbeklitepe, a parallel alternative road should be built to access the neighbouring village of Örencik, which has the same route as the 
main entrance road; thus, with this access, the entrance of any other people than a visitor and possible quarrel between the locals and the security staff would be prevented. Further, the number of cameras in the site for controlled monitoring of blind spots available in social areas and excavation site settlements should be increased, and cameras that include the visitor walking path especially around the excavation site should be set up.

\section{References} 171-189.

Baker, L. (2006). Observation: A complex research method. Library trends. 55(1),

Baraldi, S. B., Shoup, D. \& Zan, L. (2012). Understanding cultural heritage in Turkey: institutional context and organizational Issues, International Journal of Heritage Studies. 19(7), 728-748. 10.1080/13527258.2012.70028

Belmonte J. A., \& Garcia, A. C. G. (2010). Antiochos's Hierothesion at Nemrud Dag Revisited: Adjusting the Date in the Light of Astronomical Evidence. Journal for the History of Astronomy. 41 (4). 469-481. 10.1177/002182861004100403

Bilgin C., Acar V. ve Tanrısevdi A. (2020). Ören Yerlerinin Güvenlik Düzeylerinin İncelenmesine Yönelik Nitel Bir Araştırma: Aydın İli Örneği, International Journal of Contemporary Tourism Research, 4(1). 91-110.10.30625/ijctr.723

Brodie, N \& Renfrew, C. (2005). Looting and the World's Archaeological Heritage: The Inadequate Response. Annual Review of Anthropology. 5(34). 343-36. 10.1146/ annurev.anthro.34.081804.120551

Chowdhury, S. A., Ahmed, S. A. (2015). Archaeological and Historical Tourism: An Emerging Dimension for the Tourism Industry of Bangladesh Muhammad Sohel Ahmed. European Journal of Business and Management. 7-(21), 1-7.

Elia, Ricardo. (1997). Looting, collecting, and the destruction of archaeological resources. Natural Resources Research. 6. 85-98. 10.1007/BF02803807

Erarslan, Fehmi \& Özman, Recep \& Şancı, Fuat \& Arslan, Muhammet \& Karaca, Mehmet \& Alkan, Mehmet. (2009). Perre Antik Kenti Nekropol Alanı 2008 Y1l Kazı ve Temizlik Çalışmaları / Excavation and Cleaning Works in Perre Ancient City Necropolis Area in 2008. 18. Müze Çalışmaları ve Kurtarma Kazıları Sempozyumu (27-30 Nisan 2009 Sivas). Retrieved from https://www.researchgate.net/publication/33347995 _ Perre_Antik_Kenti_Nekropol_Alani_2008_Yili_Kazi_ve_Temizlik_Calismalari

Fernández Laso, M. C. (2020), "El impacto del terrorismo internacional en el patrimonio cultural: control de riesgos y protección", PASOS: Revista de Turismo y Patrimonio Cultural, 18(4), 559-569.

Hofstede, G. (1980). Culture's Consequences: International differences in workrelated values. Beverly Hills, USA: Sage.

İlahiyat Dergisi-Cumhuriyet Theology Journal. 21(2). 1107-1138. 10.18505/ cuid. 334942 
Kültürel Alanların Güvenliği, İç Güvenlik Stratejileri Dairesi Başkanlığı Yayınları (2020).

Kurt, A.O. \& Göler, M. E. (2017). The First Temple in Minor Asia: Gobeklitepe. Cumhuriyet

Muhall, A. (2003). In the field: notes on observation in qualitative research. Journal of advanced nursing. 41(3), 306-313.

Nafziger J.A.R., Paterson, R. K. Renteln, A. D. (2010). Cultural law international, comparative, and indigenous. New York, USA: Cambridge University Press

Nickens, P. R. (1991). The Destruction of Archaeological Sites and Data. In Smith,G. S. \& Ehrenhard, J. E. (eds). Protecting the Past. Florida, USA: CRC Press.

Rizzi, G. (2007). Preface. In J. Ashurst (ed). Conservation of Ruins.Oxford, U.K.: Elsevier/Butterworth-Heinemann.

Şahin, S. (1998). Kommagene Ülkesi ve Tanrılar Tahtı Nemrut Dağ, N. Başgelen (ed.), Tanrılar Dağı Nemrut. İstanbul, Türkiye: Arkeoloji ve Sanat Yayınları.

Schmidt, K. (2010). Göbekli Tepe - The Stone Age Sanctuaries. New results of ongoing excavations with a special focus on sculptures and high reliefs. Documenta Praehistorica a XXXVII. 37. 239. https://doi.org/10.4312/dp.37.21

Silverman, H. \& Ruggles D. H. (2007). Cultural Heritageand Human Rights. New York, U.S.A: Springer Science + Business Media, LLC.

Smith, Peter \& Peterson, Mark \& Schwartz, Shalom \& Ahmad, Abd Halim \& Akande, Adebowale \& Andersen, Jon \& Ayestarán, Sabino \& Bochner, Stephen \& Callan, Victor \& Davila, Carlos \& Ekelund, Bjørn \& François, Pierre-Henri \& Graversen, Gert \& Harb, Charles \& Jesuino, Jorge \& Kantas, Aristotle \& Karamushka, Lyudmila \& Koopman, Paul \& Leung, Kwok \& Yanchuk, Vladimir. (2002). Cultural values, sources of guidance, and their relevance to managerial behavior: A 47-nation study. Journal of Cross-Cultural Psychology. 33. 188-208. 10.1177/0022022102033002005

Tanaka, E. (2013). Cultural Heritage Issues in Turkey and the Category of 'Europe': Roman Mosaic Collections Discovered in Zeugma, Southeast Turkey, Senri Ethnological Studies. 81.149-168. http://doi.org/10.15021/00002481

Tan, T. (2017). The Hellenistic Tumulus of Eşenköy in NW Turkey. Anatolia Antiqua. 437. 33-52 https://doi.org/10.4000/anatoliaantiqua.43

T.C. Resmi Gazete. (1987). Korunması Gerekli Taşınmaz Kültür ve Tabiat Varlıklarının Tespit-Tescili ve Sit Alanı İlânı Sırasındaki Müktesep Hakların Korunması ile İlgili Yönetmelik. Retrived from https:/www.resmigazete.gov.tr/arsiv/19660.pdf

Töngör, A. R., (2018). Prevention of illegal trafficking and transfer of cultural properties in the light of united nations conventions. MANAS Journal of Social Studies. 7(2). 91-110. 
Williams, R. (1976). Keywords: A Vocabulary of Culture and Society. London, U.K.: Fontara.

Y1ld1z, S. (2010). The Model of Turkey in Legal Protection of Cultural Heritage. International Archives of Photogrammetry, Remote Sensing and Spatial Information Sciences, XXXVIII (5), 627-632.

Destekleyen Kurum/Kuruluşlar: Herhangi bir kurum/kuruluştan destek alınmamış̧tı.

Çıkar Çatış̧ması: Herhangi bir çıkar çatışması bulunmamaktadır 